\title{
FAKTOR-FAKTOR YANG MEMPENGARUHI KEBIJAKAN DIVIDEN PADA PERUSAHAAN MANUFAKTUR DI BURSA EFEK INDONESIA
}

\author{
Ida Ayu Putri Pertami Dewi ${ }^{1}$ \\ Ida Bagus Panji Sedana ${ }^{2}$
}

\author{
${ }^{1,2}$ Fakultas Ekonomi dan Bisnis Universitas Udayana, Bali, Indonesia \\ Email: putripertamid@gmail.com
}

\begin{abstract}
ABSTRAK
Pembagian dividen pada perusahaan kepada para investor ditentukan melalui suatu kebijakan dividen. Faktor-faktor yang dapat mempengaruhi kebijakan dividen diantaranya adalah profitabilitas, likuiditas, tingkat pertumbuhan perusahaan, dan ukuran perusahaan. Penelitian ini bertujuan untuk mengetahui signifikansi tingkat pertumbuhan perusahaan dan ukuran perusahaan terhadap kebijakan dividen pada perusahaan manufaktur di Bursa Efek Indonesia periode 2011-2015. Populasi pada penelitian ini adalah seluruh perusahaan manufaktur di Bursa Efek Indonesia pada periode 2011-2015. Sampel yang diperoleh berdasarkan pada teknik purposive sampling, dan diperoleh 9 perusahaan. Teknik analisis data yang digunakan adalah analisis regresi linear berganda. Hasil analisis menunjukan bahwa profitabilitas, likuiditas, ukuran perusahaan berpengruh positif dan signifikan terhadap kebijakan dividen sedangkan hasil analisis dari tingkat pertumbuhan pertumbuhan perusahaan berpengaruh negatif dan signifikan terhadap kebijakan dividen pada perusahaan manufaktur di Bursa Efek Indonesia.
\end{abstract}

Kata Kunci: profitabilitas, likuiditas, tingkat pertumbuhan perusahaan, ukuran perusahaan, kebijakan dividen

\begin{abstract}
The dividend distribution to the company to investors is determined through a dividend policy. Factors influencing dividend policy include profitability, liquidity, company growth rate, and firm size. This study aims to find out the significance of company growth rate and firm size to dividend policy on manufacturing companies in Indonesia Stock Exchange period 2011-2015. The population in this study is all manufacturing companies in Indonesia Stock Exchange in the period 2011-2015. The sample obtained is based on purposive sampling technique, and obtained 9 companies. Data analysis technique used is multiple linear regression analysis. The result of analysis shows that profitability, liquidity, firm size is positive and significant to dividend policy while the analysis result of growth rate of company has negative and significant influence to dividend policy at manufacturing company in Indonesia Stock Exchange
\end{abstract}

Keywords: profitability, liquidity, company growth rate, firm size, dividend policy 
Ida Ayu Putri Pertami Dewi, Faktor-faktor yang Mempengaruhi...

\section{PENDAHULUAN}

Setiap perusahaan memiliki tujuan untuk memaksimalkan laba untuk dapat mensejahterakan pemiliknya (shareholder), melaui keputusan investasi, keputusan pendanaan dana, dan kebijakan dividen yang dilakukan oleh manajer keuangan. Perusahaan menjalankan kegiatan operasionalnya memerlukan sumber dana. Investasi merupakan salah satu kegiatan yang dapat membantu kegiatan pendanaan. Investasi pada saat ini menjadi aktivitas yang dapat dilakukan untuk memperoleh keuntungan dalam pemenuhan kebutuhan suatu industri. Pihak yang merasa memiliki dana lebih akan menginvestasikan dananya dengan menginvestasikan dana tersebut melalui investasi nyata maupun investasi keuangan. Menurut Fahmi (2012:4), investasi nyata (real investment) adalah bentuk investasi yang melibatkan aset berwujud seperti tanah, gedung, mesin mesin dan pabrik, sedangkan investasi keuangan (financial investment) adalah bentuk investasi yang melibatkan kontrak tertulis seperti saham (common stock) dan obligasi (bond). Investor yang ingin menanamkan modalnya di pasar modal akan membantu industri-industri yang mengalami kesulitan dalam melakukan pendanaan.

Para investor menanamkan modalnya pada saham di sebuah perusahaan dengan tujuan utama yaitu untuk memperoleh pengembalian investasi (return) yang berupa dividen dan capital gain. Menurut Brigham dan Houston (2014: 10), sudah sewajarnya jika investor mengharapkan return yang setinggi-tingginya dari investasi yang dilakukannya. Terdapat hal penting yang harus selalu dipertimbangkan yaitu seberapa besar risiko yang harus ditanggung dari investasi 
itu sendiri. Risiko yang ditanggung investor pada saat berinvestasi saham adalah risiko tidak mendapatkan dividen, ketika perusahaan tidak bisa mengahasilkan keuntungan akan memperoleh capital loss yaitu selisih negatif antara harga jual dengan harga beli (Hermanungsih, $2012: 81$ ).

Dividen merupakan sebagian atau seluruh laba perusaahaan dalam menjalankan bisnis yang dibagikan kepada pemegang saham (Tandelilin, 2014: 32). Dalam pembagian dividen di suatu perusahaan perusahaan harus menentukan keputusan yang harus diambil melalui kebijakan dividen. Kebijakan dividen adalah bagian yang tidak terpisahkan dalam keputusan pendanaan perusahaan (Van Horne dan Wachowicz, 2012:270). Kebijakan dividen menyangkut masalah penggunaan laba yang menjadi hak pemegang saham (Wiagustini, $2014: 255$ ). Kebijakan dividen sering menimbulkan konflik kepentingan antara pihak manajemen perusahaan dengan pihak pemegang saham. Kebijakan dividen merupakan suatu keputusan yang sulit bagi pihak manajemen perusahaan, karena pembagian dividen di satu sisi akan memenuhi harapan investor untuk mendapatkan return sebagai keuntungan dari investasi yang dilakukannnya, sedangkan di sisi lain bagi perusahaan dengan pembagian dividen diharapkan tidak akan mengancam kelangsungan dari perusahaan tersebut. Manajemen perusahaan harus dapat menentukan suatu kebijkan dividen yang optimal yang dapat menjadi suatu kebijakan yang adil antara pemegang saham dengan dividen dan perusahaan dengan pertumbuhan perusahaan. Berkaitan dengan dividen, para investor umumnya menginginkan pembagian dividen yang stabil. Pembagian dividen yang relatif stabil akan meningkatkan kepercayaan investor terhadap 
Ida Ayu Putri Pertami Dewi, Faktor-faktor yang Mempengaruhi...

perusahaan, karena akan mengurangi ketidakpastian investor dalam menanamkan modalnya ke perusahaan (Sandy dan Asyik, 2013).

Kebijakan dividen tergambar pada dividend payout ratio, yaitu persentase laba yang dibagikan dalam bentuk dividen tunai, artinya besar kecilnya dividend payout ratio akan mempengaruhi keputusan investasi para pemegang saham dan di sisi lain dapat berpengaruh terhadap kondisi keuangan perusahaan. Semakin besar tingkat laba yang dibagikan dalam bentuk dividen akan membuat calon investor semakin menarik dan itu dapat menunjukan kondisi perusahaan yang sehat dan memiliki prospek yang bagus untuk kedepannya. Perusahaan yang memilih untuk membagikan laba sebagai dividen akan mengurangi total sumber dana internal. Perusahaan yang memilih untuk menahan laba yang diperoleh akan mengakibatkan kemampuan pembentukan dana internal yang semakin besar (Sartono, 2014:281).

Berdasarkan pengaruh penting dari kebijakan dividen baik itu dari perusahaan maupun investor, yang dapat dikatakan sebagai perusahaan yang menguntungkan adalah perusahaan yang mampu membayarkan dividennya (Sari dan Sudjarni, 2015). Kebijakan dividen sangat penting bagi perusahaan untuk dapat menentukan apakah laba yang diperoleh perusahaan harus dibagikan kepada pemegang saham atau akan ditahan untuk dapat membantu menunjang pertumbuhan dari perusahaan. Kebijakan dividen di suatu perusahaan akan menentukan pembagian dividen bagi pemegang saham. 
Persentase Dividen Payout Ratio pada Perusahaan Manufaktur di BEI yang membagikan dividen secara berturut turut pada periode 2011-2015 dapat ditunjukan pada gambar berikut ini :

Tabel 1.

Persentase Perusahaan Manufaktur di BEI yang Membagikan Dividen Secara Berturut-turut pada Periode 2011-2015

\begin{tabular}{ccccccc}
\hline \multirow{2}{*}{ No } & \multirow{2}{*}{ KodeEmiten } & \multicolumn{5}{c}{ DPR \% } \\
\cline { 3 - 7 } & & $\mathbf{2 0 1 1}$ & $\mathbf{2 0 1 2}$ & $\mathbf{2 0 1 3}$ & $\mathbf{2 0 1 4}$ & $\mathbf{2 0 1 5}$ \\
\hline 1 & ASGR & 39,87 & 59,88 & 40,01 & 39,91 & 47,31 \\
\hline 2 & GGRM & 39,88 & 38,35 & 35,56 & 48,02 & 48,02 \\
\hline 3 & SMGR & 39,89 & 45,00 & 45,00 & 40,00 & 40,00 \\
\hline 4 & INDF & 39,90 & 49,81 & 49,80 & 49,72 & 49,70 \\
\hline 5 & HMSP & 48,02 & 57,29 & 75,71 & 48,02 & 99,89 \\
\hline 6 & KLBF & 39,92 & 66,77 & 44,97 & 43,41 & 44,14 \\
\hline 7 & CPIN & 39,94 & 28,10 & 48,02 & 48,02 & 48,02 \\
\hline 8 & UNVR & 48,02 & 99,96 & 99,93 & 48,02 & 48,02 \\
\hline 9 & TOTO & 40,88 & 41,99 & 41,88 & 28,66 & 43,42 \\
\hline Rata-rata & & 41,81 & 54,13 & 53,43 & 43,75 & 52,06 \\
\hline
\end{tabular}

Sumber: Laporan Keuangan Tahunan Perusahaan Manufaktur di BEI Periode 2011-2015

Berdasarkan Tabel 1 dapat diketahui bahwa fenomena dividend payout ratio yang terjadi pada Perusahaan Manufaktur di Bursa Efek Indonesia periode 20112015 yang membagikan dividen secara berturut - turut pada periode tersebut mengalami fluktuasi pada setiap tahunnya. Persentase dividend payout ratio yang berfluktuasi setiap tahunnya dapat disebabkan oleh faktor - faktor tertentu yang ditentukan oleh perusahaan. Adanya masalah tersebut membuat saya mengangkat topik kebijakan dividen, dan pada penelitian ini saya ingin mengetahui apa yang menjadi faktor-faktor yang menjadi pertimbangan suatu kebijakan dividen dalam suatu perusahaan pada setiap tahunnya. Faktor - faktor yang menjadi pertimbangan dalam pembagian dividen sangatlah banyak, namun pada penelitian 
Ida Ayu Putri Pertami Dewi, Faktor-faktor yang Mempengaruhi...

ini saya memilih profitabilitas, likuiditas, tingkat pertumbuhan dan ukuran perusahaan.

Profitabilitas merupakan kemampuan suatu perusahaan untuk memperoleh laba (Sartono, 2014:122). Menurut Kasmir (2016:196) rasio profitabilitas merupakan rasio untuk menilai kemampuan perusahaan dalam mencari keuntungan. Rasio ini juga memberikan ukuran tingkat efektivitas manajemen suatu perusahaan. Salah satu yang menjadi faktor penentuan pembayaran dividen yang menjadi acuann dalah laba yang diperoleh perusahaan. Laba yang diperoleh oleh perusahaan tersebutlah yang digunakan untuk membayar dividen kepada pemegang saham. Semakin besar tingkat laba yang diperoleh akan mempengaruhi pembayaran dividen yang akan dibagikan kepada investor. Profitabilitas pada penelitian ini, diproksikan dengan return on equity (ROE). Menurut Deitiana (2009), return on equity (ROE) merupakan indikator yang tepat dalam mengukur suatu keberhasilan bisnis dengan mensejahterakan pemegang sahamnya.

Menurut Issa (2015), Musiega et al. (2013), Juhandi et al. (2013), Silaban dan Purnawati(2016), menyatakan bahwa profitabilitas berpengaruh positif dan signifikan terhadap kebijakan dividen. Sedangkan hasil penelitian yang berbeda dikemukakan oleh Sari dan Sudjarni (2015) yang menyatakan profitabilitas tidak berpengaruh terhadap kebijakan diividen. Afza dan Mirza (2011), Parsian dan Shams (2013), Ahmed (2015) juga menyatakan bahwa profitabilitas berpengaruh negatif terhadap kebijakan dividen.

Likuiditas berguna untuk mengetahui kemampuan perusahaan dalam membiayai dan memenuhi kewajiban atau utang pada saat ditagih atau jatuh 
tempo (Kasmir,2016:145). Likuiditas merupakan kemampuan perusahaan untuk membayar kewajiban financial jangka pendeknya tepat pada waktunya, likuiditas perusahaan ditunjukan oleh besar kecilnya aktiva lancar yaitu aktiva yang mudah diubah menjadi kas yang meliputi kas, surat berharga, piutang, persediaan (Sartono, 2014:116). Likuiditas pada penelitian ini diproksikan dengan current ratio (CR). Current Ratio merupakan ukuran yang secara umum digunakan untuk mengetahui kesanggupan memenuhi kewajiban jangka pendek. Likuiditas perusahaan merupakaan bagian dari pertimbangan utama dalam kebijakan dividen. Bagi perusahaan, dividen adalah arus kas keluar, dan hal tersebut mempengaruhi posisi dari kas perusahaan. Semakin besar posisi kas dan posisi likuiditas perusahaan secara keseluruhan juga semakin besar kemampuan perusahaan untuk membayar dividen (Sartono, 2014: 293).

Menurut penelitian yang dilakukan oleh Wicaksana (2012), Tabril et al. (2015), Mui dan Mustapha (2016) menyatakan bahwa likuiditas berpengaruh positif dan signifikan terhadap kebijakan dividen. Hakeem dan Bambale (2016), Aqel (2016) juga menyatakan bahwa likuiditas berpengaruh signifikan terhadap kebijakan dividen. Sebaliknya penelitian Grifin (2010), Novatiani dan Oktaviani (2012) menyatakan bahwa likuiditas berpengaruh negatif dan signifikan terhadap kebijakan dividen. Penelitian yang dilakukan Ahmed (2015) menyatakan likuiditas berpengaruh negatif dan tidak signifikan terhadap kebijakan dividen.

Tingkat pertumbuhan perusahaan dapat mempengaruhi dari kebijakan dividen. Tingkat pertumbuhan perusahaan yang semakin cepat mengakibatkan makin besar kebutuhan dana untuk waktu mendatang untuk membiayai 
Ida Ayu Putri Pertami Dewi, Faktor-faktor yang Mempengaruhi...

pertumbuhannya (Riyanto,2013: 267). Pertumbuhan dari perusahaan dapat dilihat melalui pertumbuhan aset yang dimiliki perusahaan setiap tahunnya. Tingkat pertumbuhan pada penelitian ini diproksikan dalam growth dengan melihat jumlah aset pada saat ini dengan aset sebelumnya. Menurut Brigham dan Houston (2013:211) pertumbuhan perusahaan akan mempengaruhi kebijakan dividen dimana tingkat pertumbuhan yang baik perusahaan tentunya akan mengalokasikan dana yang di dapat perusahaan untuk berinvestasi sehingga akan mengurangi pembagian dividen kepada para pemegang saham.

Dewi dan Panji (2013) pada penelitiannya menyatakan bahwa tingkat pertumbuhan perusahaan berpengaruh negatif terhadap kebijakan dividen. Parsian dan Shams (2016), Silaban dan Purnawati (2016)menyatakan bahwa tingkat pertumbuhan perusahaan berpengaruh negatif dan signifikan terhadap kebijakan dividen. Sebaliknya, Afza dan Mirza (2011), Tabril et al. (2015), Hakeem dan Bambale (2016), Aqel (2016) ), Kulathunga dan Azzes (2016) dan Ismail (2016), dalam penelitiannya menyatakan tingkat pertumbuhan perusahaan memang berpengaruh positif dan signifikan terhadap kebijakan dividen. Musiega et al. (2013) dalam penelitiannya menyatakan bahwa tingkat pertumbuhan berpengaruh positif terhadap kebijakan dividen

Ukuran perusahaan adalah rata - rata total penjualan bersih untuk tahun yang bersangkutan sampai beberapa tahun kemudian (Brigham dan Houston, 2013: 117). Ukuran perusahaan menggambarkan besar kecilnya suatu perusahaan yang ditunjukan oleh total aktiva, jumlah penjualan, rata - rata penjualan (Riyanto, 2013:305). Ukuran perusahaan adalah salah satu ukuran atau besarnya sebuah 
perusahaan yang dapat dilihat dengan besarnya aktiva yang dimiliki oleh perusahaan (Wimelda dan Marlinah, 2013). Ukuran perusahaan pada penelitian ini diproksikan dengan logaritma dari total aset, untuk dapat mengukur jumlah nilai kekayaan yang dimiliki suatu perusahaan. Menurut Kardeniz et al. (2009), perusahaan besar cenderung lebih terdiversifikasi dan lebih tahan terhadap risiko kebangkrutan dan memiliki kemungkinan lebih rendah mengalami kesulitan keuangan. Sehingga perusahaan yang besar akan lebih mampu untuk dapat membayarkan dividen kepada pemegang saham. Perusahaan - perusahaan dengan ukuran yang lebih besar akan lebih mampu membayarkan dividen dibandingkan dengan ukuran yang lebih kecil (Mehta, 2012). Ukuran perusahaan yang besar cenderung akan membagikan dividen yang lebih besar dibandingkan dengan perusahaan kecil, karena untuk perusahaan yang memiliki aset besar akan lebih mudah untuk memasuki pasar modal. Kemudahan tersebut berarti untuk fleksibilitas dan kemampuannya untuk memperoleh dana yang lebih besar, sehingga perusahaan mampu memiliki rasio pembayaran dividen yang lebih tinggi dibandingkan perusahaan kecil. Semakin besar ukuran perusahaan maka dividen yang dibagikan akan semkin besar juga.

Imran (2011), Ranti (2013), Issa, (2015), Kulathunga dan Azzes (2016) dalam penelitiannya menyatakan ukuran perusahaan berpengaruh positif dan signifikan terhadap kebijakan dividen. Aqel (2016), Mui dan Muzlina (2016) pada penelitiannya menyatakan bahwa ukuran perusahaan berpengaruh signifikan terhadap kebijakan dividen. Namun hasil yang berbeda dikemukakan oleh Afza dan Mirza (2011), Novatiani dan Oktaviani (2012) Arif dan Fatima (2013), 
Ida Ayu Putri Pertami Dewi, Faktor-faktor yang Mempengaruhi...

Juhandi et al. (2013), Musiega et al. (2013), Aqel (2016), Khalid (2015) yang menyatakan bahwa ukuran perusahaan berpengaruh negatif dan tidak signifikan terhadap kebijakan dividen. Parsian dan Shams (2016) menyataka bahwa ukuran perusahaan tidak berpengaruh signifikan terhadap kebijakan dividen.

Tujuan pada penelitian ini adalah untuk mengetahui signifikansi pengaruh profitabilitas terhadap kebijakan dividen, untuk mengetahui signifikansi pengaruh likuiditas terhadap kebijakan dividen, untuk mengetahui signifikansi pengaruh tingkat pertumbuhan perusahaan terhadap kebiijakan dividen dan untuk mengetahui signifikansi pengaruh ukuran perusahaan terhadap kebijakan dividen.

Penelitian ini diharapkan dapat memberikan kegunaan penelitian ini adalah sebagai berikut Kegunaan teoritis yaitu penelitian ini diharapkan memeberikan kontribusi dalam bentuk empiris kepada peneliti selanjutnya mengenai pengaruh dari profitabilitas, likuiditas, tingkat pertumbuhan dan ukuran perusahaan terhadap kebijakan dividen sedangkan kegunaan praktis yaitu Penelitian ini juga bisa memberikan gambaran dan informasi kepada investor sebagai landasan awal mengambil keputusan dalam berinvestasi.

Menurut Wirjolukito et al. dalam Suharli (2007) menyatakan bahwa pihak manajemen akan membayarkan dividen untuk memberikan sinyal mengenai keberhasilan perusahaan dalam membukukan profit. Sinyal tersebut menyimpulkan bahwa kemampuan perusahaan untuk membayar dividen merupakan fungsi dari keuntungan. Perusahaan yang meperoleh profit lebih besar cenderung akan mengguanakan keuntungannya untuk membayar dividen. Semakin besar profit yang dihasilkan perusahaan maka akan semakin besar pula 
perusahaan akan mebayar dividen. Menurut penelitian Pasadena (2013) faktor profitabilitas juga berpengaruh terhadap kebijakan dividen karena dividen adalah laba bersih yang diperoleh perusahaan, oleh karena itu dividen akan dibagikan apabila perusahaan memperoleh keuntungan. Keuntungan yang layak dibagikan kepada pemegang saham adalah keuntungan setelah perusahaan memenuhi kewajiban - kewajiban tetapnya yaitu bunga dan pajak. Berdasarkan teori dan hasil penelitian terdahulu, maka hipotesis yang diajukan dalam penelitian ini adalah:

$\mathrm{H}_{1}$ : Profitabilitas berpengaruh positif dan signifikan terhadap kebijakan dividen.

Likuiditas digunakan oleh investor untuk mengamati laporan keuangan perusahaan dari sisi likuiditasnya dengan cepat dan mudah. Rasio likuiditas memperlihatkan hubungan antara kas dengan aktiva lancar dan kewajiban lancar perusahaan. Aktiva yang dapat tergolong liquid adalah aktiva yang dapat dikonversi menjadi kas secara cepat tanpa harus banyak mengurangi harga aktiva itu. Menurut Sartono (2014:293) likuiditas mempunyai hubungan yang searah dengan kebijakan dividen dimana semakin besar likuiditas suatu peruahaan maka akan semakin besar pula kemampuan perusahaan dalam membayar dividen. Penelitian dari Wicaksana (2012), Tabril et al. (2015), Mui dan Mustapha (2016) menyatakan bahwa likuiditas berpengaruh positif dan signifikan terhadap kebijakan dividen. Hakeem dan Bambale (2016) juga menyatakan bahwa likuiditas berpengaruh signifikan terhadap kebijakan dividen. Berdasarkan teori 
Ida Ayu Putri Pertami Dewi, Faktor-faktor yang Mempengaruhi...

dan hasil penelitian terdahulu, maka hipotesis yang diajukan dalam penelitian ini adalah:

$\mathrm{H}_{2}$ : Likuiditas berpengaruh positif dan signifikan terhadap kebijakan dividen.

Sulistyowati et al. (2010) menyatakan bahwa tingkat pertumbuhan perusahaan merupakan salah satu yang mempengaruhi kebijakan dividen. Menrut Brigham dan Houston (2013:211) pertumbuhan perusahaan akan mempengaruhi kebijakan dividen dimana dengan tingkat pertumbuhan yang baik perusahaan tentunya akan mengalokasikan dana yang di dapat perusahaan untuk berinvestasi sehingga akan mengurangi pembagian dividen kepada para pemegang saham. Konsep packing order theory mengemukakan bahwa perusahaan menyukai internal financing (pendanaan dari hasil operasi perusahaan, yang berwujud laba ditahan).

Perusahaan yang menginginkan pertumbuhan akan menggunakan dana internalnya terlebih dahulu maka semakin cepat tingkat pertumbuhan suatu perusahaan, maka semakin besar kebutuhan dana yang diperlukan untuk biaya pertumbuhan perusahaan tersebut (Husnan, Pudjiastuti, 2012 : 311). Hal ini menunjukan semakin tinggi tingkat pertumbuhan dari perusahaan maka akan semakin kecil kemungkinan dibayarkannya dividen kepada pemegang saham. Berdasarkan teori dan hasil penelitian terdahulu, maka hipotesis yang diajukan dalam penelitian ini adalah:

$\mathrm{H}_{3}$ : Tingkat Pertumbuhan Perusahaan berpengaruh negatif dan signifikan terhadap kebijakan dividen. 
Handayani dan Hadinugroho, (2012:66) menyatakan perusahaan yang memiliki ukuran yang besar akan lebih mudah memasuki pasar modal sehingga dengan kesempatan ini perusahaan membayar dividen dengan jumlah besar kepada pemegang saham. Sementara perusahaan yang baru dan yang masih kecil akan mengalami banyak kesulitan untuk memiliki akses ke pasar modal, sehingga seakin besar ukuran perusahaan semakin mudah untuk mendapatkan modal eksternal dalam jumlah yang lebih besar terutama dari hutang. Menurut Budi (2009), hal ini terjadi karena kemudahan berhubungan dengan pasar modal berarti memiliki fleksibilitas yang lebih besar dalam kemampuan untuk mendapatkan dana dalam jangka pendek, perusahaan yang lebih besar dapat mengusahakan pembayaran dividen yang lebih besar dibandingkan dengan perusahaan yang kecil. Hal ini menunjukkaan hubungan, bahwa semakin besar ukuran perusahaan maka semakin besar pula dividen yang akan dibagikan. Berdasarkan teori dan hasil penelitian terdahulu, maka hipotesis yang diajukan dalam penelitian ini adalah:

\footnotetext{
$\mathrm{H}_{4}$ : Ukuran Perusahaan berpengaruh positif dan signifikan terhadap kebijakan dividen.
}

\section{METODE PENELITIAN}

Penelitian ini termasuk dalam golongan penelitian asosiatif. Penelitian asosiatif merupakan penelitian yang bertujuan untuk mengetahui pengaruh ataupun juga hubungan antara dua variabel atau lebih (Sugiyono, 2014:55). Penelitian ini dilakukan untuk dapat mengetahui pengaruh antara profitabilitas, 
likuiditas, tingkat pertumbuhan perusahaan dan ukuran perusahaan terhadap kebijakan dividen.

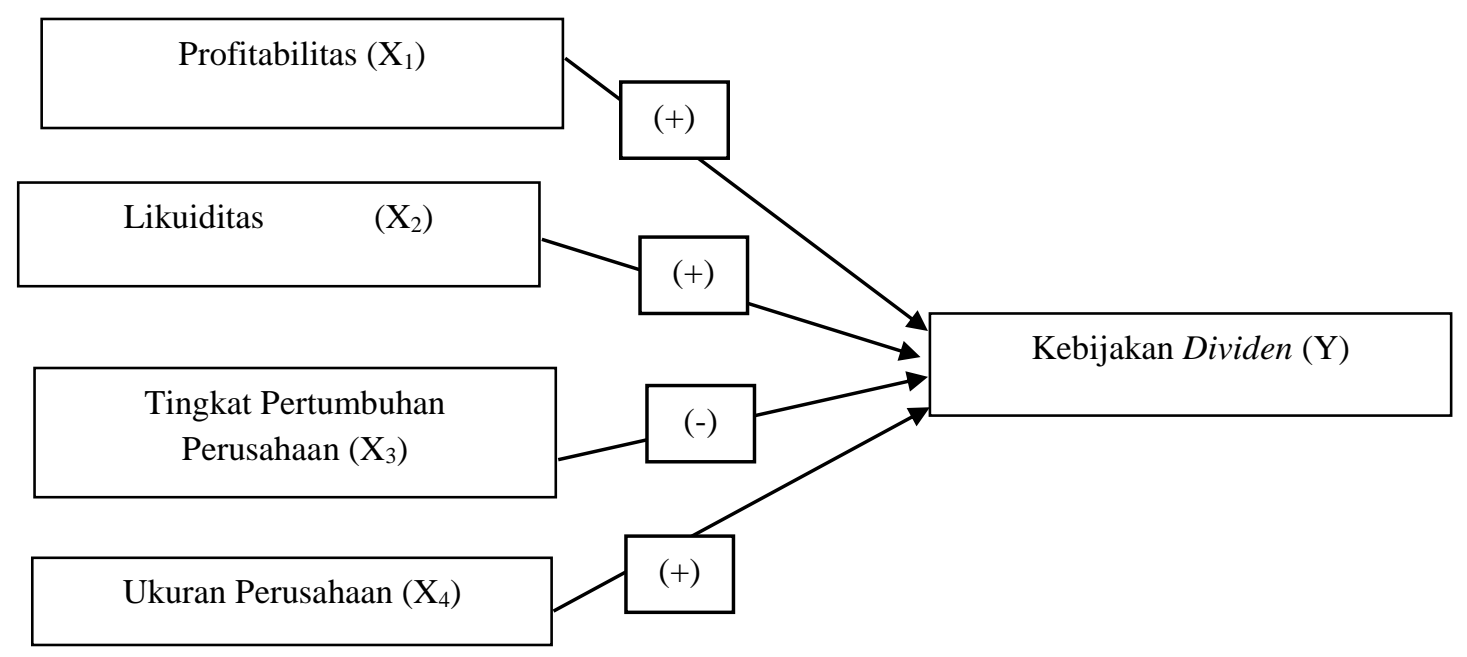

\section{Gambar 1. Kerangka Pemikiran}

Sumber: Data Primer Diolah, 2017

Lokasi pada penelitian ini dilakukan pada perusahaan manufaktur yang terdaftar di Bursa Efek Indonesia (BEI). Lokasi ini dipilih karena BEI menyediakan data perusahaan yang telahgo public dan telah memenuhi syarat tertentu sebagai perusahaan yang tergolong memiliki kinerja yang baik. Lokasi ini dapat diakses dari laman resmi BEI yaitu www.idx.co.id. Obyek pada penelitian ini adalah kebijakan dividen yang dapat diukur dengan dividend payout ratio (DPR) pada perusahaan manufaktur di Bursa Efek Indonesia (BEI) periode 20112015 .

Penelitian ini menggunakan dua jenis variabel yaitu variabel bebas dan variabel terikat sebagai berikut variabel dependent / terikat yaitu sugiyono (2014: 59) menyatakan bahwa variabel dependent adalah variabel yang dipengaruhi atauyang menjadi akibat, karena adanya variabel bebas. Variabel ini juga sering 
disebut sebagai variabel output, krieria, konsekuen, atau variabel endogen. Variabel dependent pada penelitian ini yaitu Kebijakan Dividen (Y) sedangkan variabel bebas (Xi) yaitu Sugiyono (2014: 59) menyatakan bahwa variabel bebas adalah variabel yang menjadi sebab perubahan atau timbulnya variabel terikat. Variabel ini juga sering disebut stimulus, prediktor, antecedent, ataupun variabel eksogen. Adapun variabel bebas yang digunakan pada penelitian ini yaitu Profitabilitas $\left(\mathrm{X}_{1}\right)$, Likuiditas $\left(\mathrm{X}_{2}\right)$, Tingkat Pertumbuhan Perusahaan $\left(\mathrm{X}_{3}\right)$ dan Ukuran Perusahaan $\left(\mathrm{X}_{4}\right)$.

Populasi merupakan wilayah generalisasi yang terdiri atas objek atau subjek yang mempunyai kualitas dan karakteristik tertentu yang ditetapkan oleh penelii untuk dipelajari dan kemudian ditarik kesimpulannya (Sugiyono, 2014:115). Populasi dalam penelitian ini adalah seluruh perusahaan manufaktur yang terdapat di Bursa Efek Indonesia periode 2011-2015 dengan jumlah populasi sebanyak 143 perusahaan manufaktur. Sampel adalah bagian atau sebagian kecil dari populasi yang karakteristiknya hendak diselidiki (Sugiyono, 2014:116). Jumlah sampel yang sesuai dengan kriteria peneliti sebanyak 9 perusahaan manufaktur. Sampel yang diambil berdasarkan purposive sampling. Purposive sampling adalah teknik penentuan sampel dengan pertimbangan dan kriteria tertentu (Sugiyono, 2014:122). Adapun kriteria yang digunakan dalam pemilihan sampel yang akan diteliti dalam penelitian ini adalah perusahaan Manufaktur di BEI yang membagikan dividen secara berturut - turut pada periode 2011-2015.

Jenis data yang digunakan dalam penelitan ini adalah data kuantitatif. Data Kuantitatif, yaitu data yang berupa angka-angka atau data kuantitatif yang 
Ida Ayu Putri Pertami Dewi, Faktor-faktor yang Mempengaruhi...

diangkakan (Sugiyono, 2014:13). Data kuantitatif dalam penelitian ini yaitu laporan keuangan perusahaan manufaktur yang terdaftar di Bursa Efek Indonesia (BEI) periode 2011 - 2015. Berdasarkan sumbernya, data yang digunakan dalam penelitian ini adalah data sekunder yaitu data yang dikumpulkan dalam bentuk sudah jadi dan terkumpulkan dan diolah oleh pihak lain (Sugiyono, 2014:13). Data tersebut didapat dalam laporan keuangan setiap tahunnya yang dipublikasikan oleh perusahaan manufaktur yang terdapat di bursa efek indonesia (BEI) melalui situs resmi www.idx.co.id.

Metode yang digunakan dalam penelitian ini adalah metode observasi non participant, yaitu observasi terhadap dokumen atau laporan keuangan sebagai pengumpul data yang tercantum pada Indonesia Stock Exchange (IDX). Data yang diteliti tersebut dikumpulkan dengan mengamati, mencatat, serta memperlajari buku-buku yang berkaitan dengan penelitian yang dilakukan (Sugiyono,2014:204). Penelitian ini menggunakan teknik analisis model regresi linear berganda karena analisis regeresi selain mengukur kekuatan hubungan antara dua variabel atau lebih, juga menunjukkan arah hubungan antara variabel dependent dengan variabel independen (Ghozali, 2016:94). Model regresi linear berganda ini digunakan untuk mengetahui bagaimana pengaruh profitabilitas, likuiditas, tingkat pertumbuhan perusahaan dan ukuran perusahaan terhadap kebijakan dividen pada perusahaan manufaktur di Bursa Efek Indonesia perioe 2011 - 2015 dengan bantuan program SPSS (Statsistical Program and Service Solution). 
Teknik analisis ini digunakan karena dalam penelitian ini variabel terikat dipengaruhi oleh lebih dari satu variabel bebas yang dimana profitabilitas, likuiditas, tingkat pertumbuhan perusahaan dan ukuran perusahaan sebagai variabel terikat. Bentuk persamaan regresi linear berganda secara sistematis sebagai berikut (Utama, $2016: 77$ )

$$
\hat{\mathrm{Y}}=\alpha+\beta_{1} \mathrm{X}_{1}+\beta_{2} \mathrm{X}_{2}+\beta_{3} \mathrm{X}_{3}+\mathrm{ei}
$$

Keterangan :

$\hat{\mathrm{Y}} \quad=$ Kebijakan Dividen

$\alpha \quad=$ Konstanta

$\beta_{1}, \beta_{2}, \beta_{3}=$ Koefisien Regresi

$\mathrm{X}_{1} \quad=$ Profitabilitas

$\mathrm{X}_{2} \quad=$ Likuiditas

$\mathrm{X}_{3} \quad=$ Tingkat Pertumbuhan Perusahaan

$\mathrm{X} 4=$ Ukuran Perusahaan

ei $\quad=$ kesalahan residu

\section{HASIL DAN PEMBAHASAN}

Uji ini bertujuan untuk menguji apakah dalam model regresi, variabel pengganggu memiliki distribusi normal (Ghozali, 2016: 147). Uji normalitas dapat dilakukan menggunakan uji Kolmogorov- Smirnov. Apabila koefisien Asymp. Sig. (2-tailed) lebih besar dari 0,05 maka data tersebut dapat dikatakan berdistribusi normal. Hasil uji normalitas pada penelitian ini ditunjukan pada Tabel 2 berikut.

Tabel 2.

Hasil Uji Normalitas

\begin{tabular}{cc}
\hline & Unstandardized Residual \\
\hline $\mathrm{N}$ & 45 \\
\hline Kolmogorov- Smirnov Z & 1,009 \\
\hline Asymp. Sig. (2-tailed) & 0,260 \\
\hline
\end{tabular}

Sumber: Data Diolah, 2017 
Berdasarkan Tabel 2 dapat dilihat bahwa nilai Kolmogorov-Smirnov (K-S) sebesar 1,009, sedangkan nilai Asymp. Sig (2-tailed) sebesar 0,260. Hasil tersebut mengindikasikan bahwa model persamaan regresi tersebut berdistribusi normal karena nilai Asymp. Sig (2-tailed) 0,260 lebih besar dari nilai alpha 0,05.

Uji autokorelasi bertujuan untuk menguji apakah dalam model regresi linear ada korelasi antara kesalahan pengganggu pada periode $\mathrm{t}$ dengan kesalahan pengganggu pada periode t-1 (Ghozali, 2016: 104).Hasil uji autokorelasi pada penelitian ini ditunjukan pada Tabel 3.

Tabel 3.

Hasil Uji Autokorelasi

\begin{tabular}{cccccc}
\hline Model & $\mathrm{R}$ & $\mathrm{R}$ Square & Adjusted R Square & Std. Error of the Estimate & Durbin-Watson \\
\hline 1 & $0,802^{\mathrm{a}}$ & 0,644 & 0,608 & 10,02317 & 2,183 \\
\hline \multicolumn{2}{l}{ Sumber: Data Diolah, 2017} & & &
\end{tabular}

Berdasarkan Tabel 3 dapat diketahui nilai Durbin Watson (D-W) sebesar 2,183, nilai ini bila dibandingkan dengan nilai tabel signifikansi 5\%, jumlah sampel $45(\mathrm{n})$ dan jumlah variabel independen $(\mathrm{K}=4)$ maka diperoleh nilai du 1,72, dl 1,34. Nilai D-W 2,183 lebih besar dari batas atas (du) yakni 1,72 dan kurang dari (4-du) $4-1,72=2,28$ dapat disimpulkan bahwa tidak mengandung gejala autokorelasi.

Uji multikolineritas dilakukan untuk menguji apakah model regresi ditemukan adanya korelasi antar variabel bebas. Model regresi yang baik tidak terjadi korelasi diantara variabel bebas (Ghozali,2016:105).Adanya multikolineritas dapat dilihat dari nilai tolerance atau variance inflation factor (VIF). Jika nilai tolerance lebih dari 0,10 atau VIF kurang dari 10, maka dikatakan tidak ada multikolinearitas. 
Tabel 4.

Hasil Uji Multikolineritas

\begin{tabular}{llcc}
\hline & & \multicolumn{2}{c}{ Collinerity Statistics } \\
\cline { 3 - 4 } Model & & \multicolumn{2}{c}{ Tolerance } \\
\hline 1 & (Constant) & 0,855 & 1,170 \\
& R0E & 0,727 & 1,376 \\
& CR & 0,788 & 1,269 \\
& Growth & 0,983 & 1,017 \\
& Size &
\end{tabular}

Sumber: Data Diolah, 2017

Berdasarkan Tabel 4 dapat diketahui bahwa nilai tolerancedan VIF dari ROE, CR, Growth dan Size menunjukan bahwa nilai tolerance untuk setiap variabel lebih besar dari 0,01 dan nilai VIF lebih kecil dari 10 yang berarti model persamaan regresi bebas dari multikolinearitas.

Uji heteroskedastisitas bertujuan untuk menguji apakah dalam model regresi yang digunakan terjadi ketidaksamaan varians dari residual satu pengamatan ke pengamatan lain (Ghozali, 2016:125). Uji heteroskedastisitas dapat dilakukan dengan uji Glejser. Jika tidak ada satu pun variabel bebas yang berpengaruh signifikan terhadap nilai absolute residual atau nilai signifikansinya di atas 0,05 maka tidak mengandung gejala heteroskedastisitas.

Tabel 5.

Hasil Uji Heteroskedastisitas

\begin{tabular}{|c|c|c|c|c|c|c|}
\hline & \multirow[t]{2}{*}{ Model } & \multicolumn{2}{|c|}{ Unstandardized Coefficients } & \multirow{2}{*}{$\begin{array}{c}\text { Standardized } \\
\text { Coefficients } \\
\text { Beta } \\
\end{array}$} & \multirow[t]{2}{*}{$\mathrm{t}$} & \multirow[t]{2}{*}{ Sig. } \\
\hline & & $\mathrm{B}$ & Std. Error & & & \\
\hline \multirow[t]{5}{*}{1} & (Constant) & -13.981 & 11,156 & & $-1,253$ & 0,217 \\
\hline & ROE & 0,530 & 0,370 & 0,211 & 1,432 & 0,160 \\
\hline & CR & 0,200 & 0,100 & 0,303 & 1,898 & 0,650 \\
\hline & Growth & 0,186 & 0,112 & 0,254 & 1,658 & 0,105 \\
\hline & Size & 0,649 & 0,664 & 0,134 & 0,978 & 0,334 \\
\hline
\end{tabular}


Berdasarkan Tabel 5 dapat dilihat bahwa nilai Sig. dari variabel yaitu Profitabilitas (X1), Likuiditas (X2), Tingkat Pertumbuhan (X3) dan Ukuran Perusahaan (X4) masing - masing sebesar 0,160;0.650;0,105;0,334. Nilai Sig. tersebut memiliki nilai yang lebih besar dari 0.05 yang berarti tidak terdapat pengaruh antara variabel bebas terhdap absolute residual. Dengan demikian model yang dibuat dalam penelitian tidak mengandung gejala heteroskedastisitas.

Analisis regresi linear berganda digunakan untuk mengetahui arah dan besarnya pengaruh Profitabilitas, Likuiditas, Tingkat Pertumbuhan Perusahaan dan Ukuran Perusahaan terhadap kebijakan dividen pada perusahaan manufaktur di Bursa Efek Indonesia periode 2011-2015.

Tabel 6.

Hasil Analisis Regresi Linear Berganda

\begin{tabular}{|c|c|c|c|c|c|c|}
\hline \multirow{2}{*}{\multicolumn{2}{|c|}{ Model }} & \multicolumn{2}{|c|}{$\begin{array}{l}\text { Unstandardized } \\
\text { Coefficients } \\
\end{array}$} & \multirow{2}{*}{$\begin{array}{c}\begin{array}{c}\text { Standardized } \\
\text { Coefficients }\end{array} \\
\text { Beta } \\
\end{array}$} & \multirow[t]{2}{*}{$\mathbf{T}$} & \multirow[t]{2}{*}{ Sig. } \\
\hline & & B & Std. Error & & & \\
\hline \multirow[t]{5}{*}{1} & (Constant) & $-15,976$ & 19,850 & & $-0,805$ & 0,426 \\
\hline & ROE & 0,547 & 0,066 & 0,850 & 8,329 & 0,000 \\
\hline & $\mathrm{CR}$ & 0,068 & 0,019 & 0,402 & 3,627 & 0,001 \\
\hline & Growth & $-0,482$ & 0,200 & $-0,256$ & $-2,408$ & 0,021 \\
\hline & Size & 2,475 & 1,181 & 0,199 & 2,096 & 0,042 \\
\hline $\mathrm{R}^{2}$ & : & 0,644 & & & & \\
\hline & Statistik & 18,056 & & & & \\
\hline & F & 0,000 & & & & \\
\hline
\end{tabular}

\subsubsection{Analisis regresi linear berganda}

Berdasarkan Tabel 6 dapat diperoleh persamaan regresi linear berganda sebagai berikut.

$\hat{\mathrm{Y}}=-15,976+0,547 \mathrm{X}_{1}+0,068 \mathrm{X}_{2}-0,482 \mathrm{X}_{3}+2,475 \mathrm{X}_{4}$

Keterangan:

$\hat{\mathrm{Y}} \quad: \mathrm{DPR}$ 


$$
\begin{array}{ll}
\mathrm{X}_{1} & : \mathrm{ROE} \\
\mathrm{X}_{2} & : \mathrm{CR} \\
\mathrm{X}_{3} & : \text { Growth } \\
\mathrm{X}_{4} & \text { : Size }
\end{array}
$$

Persamaan regresi linear berganda tersebut menunjukkan arah masingmasing variabel bebas (ROE, CR, Growth, Size), dimana koefisien regresi variabel bebas yang bertanda negatif berarti memiliki pengaruh yang berlawanan arah terhadap kebijakan dividen, sedangkan koefisien regresi variabel yang bertanda positif memiliki pengaruh yang searah terhadap kebijakan dividen. Berdasarkan hal tersebut dapat diketahui bahwa variabel bebas yang terdiri dari ROE, CR, Sizememiliki pengaruh positif terhadap kebijakan dividen. Sedangkan Growth memiliki pengaruh negatif terhadap kebijakan dividen. Persamaan regresi tersebut dapat diuraikan sebagai berikut.

$\alpha=-15,976$ memiliki arti bahwa jika nilai variabel Profitabilitas (ROE), Likuiditas (CR), Tingkat Pertumbuhan Perusahaan (Growth), dan Ukuran Perusahaan (Size) sama dengan nol, maka nilai kebijakan dividen (DPR) sebesar $-15,976$ persen.

$\mathrm{b}_{1}=0,547$ memiliki arti bahwa setiap peningkatan 1 persen Return on Equity (ROE), maka kebijakan dividen akan mengalami peningkatan sebesar 0,547 persen dengan asumsi variabel lainnya konstan.

$\mathrm{b}_{2}=0,068$ memiliki arti bahwa setiap peningkatan 1 persen Current Ratio, maka kebijakan dividen akan mengalami peningkatan sebesar 0,068 persen dengan asumsi variabel lainnya konstan. 
Ida Ayu Putri Pertami Dewi, Faktor-faktor yang Mempengaruhi...

$\mathrm{b}_{3}=-0,482$ memiliki arti bahwa setiap peningkatan 1 persen Growth, maka kebijakan dividen akan mengalami penurunan sebesar 0,482 persen dengan asumsi variabel lainnya konstan.

$\mathrm{b}_{4}=2,475$ memiliki arti bahwa setiap peningkatan 1 persen Size, maka kebijakan dividen akan mengalami peningkatan sebesar 2,475 persen dengan asumsi variabel lainnya konstan.

Koefisien determinasi $\left(\mathrm{R}^{2}\right)$ pada intinya mengukur seberapa jauh kemampuan model dalam menerangkan variasi variabel dependen (Sugiyono, 2014:24). Nilai koefisien determinasi adalah antara nol sampai $1\left(0<\mathrm{R}^{2}<1\right)$. Nilai $\mathrm{R}^{2}$ yang kecil berarti kemampuan variabel-variabel independen dalam menjelaskan variasi variabel dependen sangat terbatas sedangkan niali yang mendekati satu berarti variabel-variabel independen memeberikan hampir semua informasi yang dibutuhkan untuk memprediksi variasi variabel dependen. Berdasarkan Tabel 6 dapat diketahui bahwa koefisien determinasi $\left(\mathrm{R}^{2}\right)$ yang diperoleh sebesar 0,644. Hal ini berarti 64,4 persen variasi variabel. Kebijakan Dividen dapat dijelaskan oleh variabel $\operatorname{ROE}\left(\mathrm{X}_{1}\right)$, CR $\left(\mathrm{X}_{2}\right)$, Growth $\left(\mathrm{X}_{3}\right)$, Size $\left(\mathrm{X}_{4}\right)$, sedangkan sisanya sebesar 35,9 persen dijelaskan oleh variabel lain yang tidak termasuk ke dalam model penelitian ini.

Hasil pengujian hipotesis pengaruh profitabilitas yang diproksikan dengan return on equity terhadap kebijakan dividen yang diproksikan dengan dividen payout ratio menunjukan bahwa profitabilitas berpengaruh positif dan signifikan terhadap kebijakandividen pada perusahaan manufaktur di Bursa Efek Indonesia periode 2011 - 2015. Hasil penelitian ini sejalan dengan penelitian Wirjolukito et 
al. dalam Suharli (2007) menyatakan bahwa pihak manajemen akan membayarkan dividen untuk memberikan sinyal mengenai keberhasilan perusahaan dalam membukukan profit. Sinyal tersebut menyimpulkan bahwa kemampuan perusahaan untuk membayar dividen merupakan fungsi dari keuntungan, maika dapat disimpulkan bahwa profitabilitas berpengaruh positif dan signifikan terhadap kebijakan dividen.

Hasil pengujian hipotesis pengaruh likuiditas yang diproksikan dengan current ratio terhadap kebijakan dividen menunjukan bahwa likuiditas berpengaruh positif dan signifikan terhadap kebijakan dividen pada perusahaan manufaktur di Bursa Efek Indonesia periode 2011 - 2015. Hasil penelitian ini sejalan dengan penelitian Adnyana (2014) yang menyatakan likuiditas yang tinggi dari perusahaan yang baik sehingga dengan likuiditas yang baik, perusahaan tidak akan kesulitan untuk memenuhi kewajiban pembayaran dividennya, kondisi tersebut akan mempengaruhi harga saham dan minat investor untuk menginvestasikan dananya pada perusahaan. Sehingga perusahaan dengan likuiditas yang baik akan menunjukan kemampuan perusahaan untuk memenuhi kewajiban jangka pendeknya, maika hal tersebut dapat meningkatkan kesempatan pembayaran dividen kepada pemegang saham. Menurut Sartono (2014:293) apabila posisi kas semakin besar dan posisi likuiditas perusahaan secara keseluruhan juga semakin besar maka kemmapuan perusahaan untuk membayar dividen juga akan semakin besar.

Hasil pengujian hipotesis pengaruh tingkat pertumbuhan perusahaan yang diproksikan dengan growth terhadap kebijakan dividen menunjukan bahwa 
Ida Ayu Putri Pertami Dewi, Faktor-faktor yang Mempengaruhi...

tingkat pertumbuhan perusahaan berpengaruh perusahaan berpengaruh negatif dan signifikan terhadap kebijakan dividen dividen pada perusahaan manufaktur di Bursa Efek Indonesia periode 2011 - 2015. Hasil penelitian ini sejalan dengan penelitian yang menyatakan semakin cepat tingkat pertumbuhan perusahaan maka semakin besar kebutuhan dana untuk membayar pembiayaan ekspansi. Maka semakin besar kebutuhan untuk pembiayaan mendatang akan semakin besar pula keinginan perusahaan untuk menahan laba yang diperoleh (Sartono, 2014:248). Sulistiyowati et al. (2010) menyatakan bahwa tingkat pertumbuhan perusahaan merupakan salah satu faktor yang mempengaruhi kebijakan dividen. Dalam konsep packing order theory dikemukakan bahwa perusahaan menyukai internal financing (pendanaan dari hasil operasi perusahaaan, yang berwujud laba ditahan.

Hasil pengujian hipotesis pengaruh ukuran perusahaan yang diproksikan dengan size terhadap kebijakan dividen menunjukan bahwa ukuran perusahaan berpengaruh positif dan signifikan terhadap kebijakan dividen pada perusahaan manufaktur di Bursa Efek Indonesia periode 2011 - 2015. Hasil penelitian ini sejalan dengan penelitian Sunarto dan Budi (2009) yang menyatakan bahwa kemudahan berhubungan dengan pasar modal berarti memiliki fleksibilitas yang lebih besar dalam kemampuan untuk mendapatkan dana dalam jangka pendek, perusahaan yang lebih besar dapat mengusahakan membayarkan dividen yang lebih besar dibandingkan dengan perusahaan yang kecil. Sehingga semakin besar ukuran perusahaan maka semakin besar pula dividen yang akan dibagikan. 


\section{SIMPULAN DAN SARAN}

Simpulan dalam penelitian ini adalah Profitabilitas berpengaruh positif dan signifikan terhadap kebijakan dividen pada perusahaan manufaktur di Bursa Efek Indonesia periode 2011 - 2015. Hal tersebut menunjukan bahwa semakin tinggi laba yang dihasilkan perusahaan maka akan semakin besar kemungkinan dividen akan dibagikan kepada para pemegang saham, Likuiditas berpengaruh positif dan signifikan terhadap kebijakan dividen pada perusahaan manufaktur di Bursa Efek Indonesia periode 2011-2015. Hal tersebut menunjukan semakin tinggi likuiditas perusahaan maka kemampuan perusahaan untuk membayar kewajiban jangka pendeknya akan semakin besar. Tingkat pertumbuhan perusahaan berpengaruh negatif dan signifikan terhadap kebijakan dividen pada perusahaan manufaktur di Bursa Efek Indonesia periode 2011-2015, dimana semakin tinggi tingkat pertumbuhan perusahaan maka perusahaan lebih memilih untuk tidak membagikan dividen kepada pemegang saham karena perusahaan akan menggunakan keuntungan yang diperoleh untuk dapat meningkatkan atau memperluas perusahaan untuk masa yang akan datang dengan melakukan investasi. Ukuran perusahaan berpengaruh positif dan signifikan terhadap kebijakan dividen pada perusahaan manufaktur di Bursa Efek Indonesia periode 2011-2015, karena semakin besar ukuran suatu perusahaan maka kamampuan perusahaan untuk membayarkan dividen kepada pemegang saham besar disebabkan perusahaan yang besar tentunya memiliki aset yang besar yang dapat digunakan untuk mambantu perusahaan mambayarkan dividen. 
Berdasarkan pembahasan hasil penelitian dan simpulan di atas, maka saran yang dapat diberikan sebagai berikut bagi investor yaitu apabila melakukan investasi pada suatu perusahaan agar lebih memperhatikan rasio profitabilitas, rasio likuiditas, dan ukuran perusahaan karena faktor - faktor tersebut mempengaruhi kebijakan dividen sedangkan bagi peneliti selanjutnya yaitu agar tidakhanya menggunakan variabel-variabel yang terdapat pada penelitian ini, tetapi dapat menggunakan variabel lain yang dapat menjadi faktor-faktor yang mempengaruhi kebijakan dividen seperti leverage, kebijakan hutang, kepemilikan manajerial, earning per share, manajemen aktiva serta peneliti selanjutnya dapat menggunakan objek penelitian tidak hanya pada perusahaan manufaktur tetapi dapat menggunakan perusahaan lain yang membagikan dividen.

\section{REFERENSI}

Adnyana, I. G. 2014. Pengaruh Likuiditas, Manajemen Aktiva, Earning Per Share dan Ukuran Perusahaan Terhadap Kebijakan Dividen dan Nilai Perusahaan Pada Perusahaan Manufaktur di Bursa Efek Indonesia (BEI). E-Jurnal Manajemen Unud, 3 (12):3707-3724.

Afza, T., dan Hassan H. M. 2011. Institutional Shareholdings and Corporate Dividend Policy in Pakistan. African Journal of Business Management, 5 (22): 8941-8951.

Ahmed, I. E. 2015. Liquidity, Profitability and the Dividends Payout Policy World Review of Business Research, 5 (2): 73 - 85.

Aqel, S. 2016. An Empirical Investigation of Corporate Dividend Payout Policy in an Emerging Market: Evidence from Palestine Securities Exchange. Research Journal of Finance and Accounting, 7 (6): 7 - 16.

Arif, A., dan Fatima A. 2013. Determinants of Dividen Policy: A Sektoral Analysis From Pakista. International Journal of Bussiness and Behavioral Sciences, 3 (9):16-33. 
Brigham, E. F., dan Joel F. H. 2013. Dasar-Dasar Manajemen Keuangan. Edisi Kesebelas, Buku II. Jakarta: Salemba Empat.

Deitiana, T. 2009. Faktor-Faktor yang Mempengaruhi Kebijakan Pembayaran Dividen Kas, Jurnal bisnis dan Akuntansi, 1 (1):38-63.

Fahmi, I. 2012. Analisis Laporan Keuangan. Lampulo: ALFABETA.

Griffin, C. H. 2010. Liquidity and Dividend Policy: International Evidence. International Business Research, 3 (3): 03-09.

Ghozali, I. 2016. Aplikasi Analisis Multivariate dengan Program IBM SPSS 23. Edisi kedelapan. Semarang: Badan Penerbit Universitas Diponegoro

Hakeem, S. A., dan Abdu, J. B. 2016. Mediating Effect of Liquidity on Firm Performance and Dividend Payout of Listed Manufacturing Companies in Nigeria. Journal of Economic Development, Management, IT, Finance and Marketing, 8 (1):15-35.

Handayani, D.R., dan Hadinugroho, B. 2009. Analisis Pengaruh Kepemilikan Manajerial, Kebijakan Hutang, ROA, Ukuran Perusahaan terhadap Kebijakan Dividen. Jurnal Fokus Manajerial, 7 (1): 64-71.

Hermanungsih, S. 2012. Pengantar Pasar Modal Indonesia. Yogyakarta: UPP STIM YKPN.

Husnan dan Pudjiastuti. 2012. Dasar-Dasar Manajemen Keuangan. UPP STIM YKPN: Yogyakarta.

http://www.idx.co.id

Imran, K. 2011. Determinants of Dividend Policy: A Case of Engineering Sektor. The Romanian Economic Journal, 14 (41): 47-60.

Ismail, Y. Y. S. 2016. Determinants of Dividend Policy of Public Listed Companies in Malaysia. Review of International Business and Strategy, 26 (1): -

Issa, Ayman. 2015. The Determinants of Dividend Policy: Evidence from Malaysian Firms. Research Journal of Finance and Accounting, 6 (8): 6987.

Juhandi, N., Sudarma, M., Aisjah, S., dan Rofiaty. 2013. The Effects of Internal factors and Stock Ownership Structure on Dividend Policy on Company's Value (A Study on Manufacturing Companies Listed on the Indonesia Stock Exchange (IDX)). International Journal of Business and Management Invention, 2 (11): 06-18. 
Kasmir. 2016. Analisis Laporan Keuangan. Cetakan Ketiga. Jakarta: PT. Raja Grafindo Persada.

Kardeniz, E., Kandir, S. Y., Balcilar, M., dan Onal, Y. B. 2009. Determinant of Capital Strukture Evidence From Turkish Lodging Companies. Managerial Finance, 21 (5): 594-609.

Khalid, S., dan Rehman, M. U. 2015. Determination of Factors effecting The Dividend Policy of Organizations. International Journal of Information, Business and Management, 7 (3): 319 - 333.

Kulathunga dan Azzes. 2016. The Impact of Ownership Structure on Dividen Policy: Evidence From Listed Companies In Sri Lanka. $6^{\text {th }}$ Annual International Conference on Qualitative and Quantitative Research (QQE 2016): $80-88$.

Mehta, A. 2012. An Empirical Analysis of Determinants of Dividend Policy Evidance from the UAE Companies. Global Review of Accounting and Finance, 3 (1): 18-31.

Mui, Y. T. dan Mustapha, M. 2016. Determinants of Dividend Payout Ratio: Evidence from Malaysian Public Listed Firms. J. Appl. Environ. Biol. Sci., 6 (1S): 48-54.

Musiega, M. G., Alala, O. B., Dougla, M., Christopher, O. M., dan Robert, E. 2013. Determinants Of Dividend Payout Policy Among Non-Financial Firms On Nairobi Securities Exchange, Kenya. International Journal Of Scientific \& Technology Research, 2 (10): 253 - 266.

Novatiani, R. A., dan Oktaviani, N. 2012. Pengaruh Profitabilitas, Likuiditas, Leverage, dan Ukuran Perusahaan Terhadap Kebijakan dividen Pada Perusahaan Manufaktur Di Sektor Industri Barang Konsumsi Yang Terdaftar Di Bursa Efek Indonesia. Jurnal Skripsi, 4 (1): 1 -24.

Nufiati, N. M. B. 2015. Pengaruh Profitabilitas, Likuiditas Terhadap Kebijakan Dividen Kas Pada Perusahaan Pefindo 25. Jurnal Ilmu dan Riset Manajemen, .4 (8): 1-18.

Parsian, H., dan Shams, A. K. 2013. A study on The Effect of Free Cash Flow and Profitability Current Ratio on Dividend Payout Ratio: Evidence from Tehran Stock Exchange. Management Science Letters 4: 63-70.

Ranti, U. O. 2013. Determinants of Dividend Policy: A study of selected listed Firms in Nigeria. Change and Leadership,(17) : $107-119$.

Riyanto, B. 2013. Dasar-Dasar Pembelanjaan Perusahaan. Edisi keempat. Yogyakarta: BPFE. 
Sandy, A., dan Asyik, N. F. 2013. Pengaruh Profitabilitas Dan Likuiditas Terhadap Kebijakan Dividen Kas Pada Perusahaan Otomotif. Jurnal Ilmu dan Riset Akuntansi, 1(1): 58-76.

Sari, K. A. N., dan Sudjarni, L. K. 2015. Pengaruh Likuiditas, Leverage, Pertumbuhan Perusahaan dan Profitabilitas Terhadap Kebijakan Dividen Pada Perusahaan Manufaktur di BEI. E- Jurnal Manajemen Unud, 4 (10): 3346-3374.

Sartono, A. 2014. Manajemen Keuangan Teori dan Aplikasi. Edisi Empat. Cetakan Ketujuh. Yogyakarta:BPFE.

Silaban, D. P. dan Purnawati, N. K. 2016. Pengaruh Profitabilitas, Struktur Kepemilikan, Tingkat Pertumbuhan, dab Efektivitas Usaha Terhadap Kebijakan Dividen di Perusahaan Manufaktur. E-Jurnal Manajemen Unud, 5 (2): 1251-1281.

Sugiyono, 2014. Metode Penelitian Bisnis. Bandung : Alfabeta, CV.

Suharli, M. 2007. Pengaruh Profitability dan Investment OpportunitySet Terhadap Kebijakan Dividen Tunai dengan Likuiditas sebagai Variabel Penguat. Jurnal Akuntansi dan Keuangan, 9 (1): 9-17.

Sulistiyowati, I., Anggraini, R., dan Utaminingtyas, T. H. 2010. Pengaruh Profitabilitas, Leverage, dan Growth Terhadap Kebijakan Dividen dengan Good Corporate Governance sebagai Variabel Intervenin. Simposium Nasional Akuntansi XIII. Purwokerto.

Sunarto dan Budi, A. P. 2009. Pengaruh Leverage, Ukuran dan Pertumbuhan Perusahaan Terhadap Profitabilitas. Jurnal Ilmiah Telaah Manajemen, 6 (1):86-103.

Tandelilin, E. 2014. Portofolio dan Investasi Teori dan Aplikasi. Edisi Pertama. Yogyakarta:BPFE

Tabril, N. A. Y. Z., dan Shirazi, S. 2015. Examining The Determinants of Dividen Policy In Listed Companies In Teheran Stock Exchange. Indian Journal of Fundamental and Applied Life Sciences, 5 (S3): 2375-2382.

Utama, S. 2016. Aplikasi Analisis Kuantitatif. Edisi Kesepuluh. Denpasar: Fakultas Ekonomi dan Bisnis Universitas Udayana.

Horne, V., James, C. dan Junior W. J. M. 2012. Prinsip - prinsip Manajemen Keuangan, Buku 1, Edisi 12. Jakarta: Salemba Empat.

Wiagustini, N. L. P. 2014. Manajemen Keuangan. Denpasar: Udayana University Press. 
Ida Ayu Putri Pertami Dewi, Faktor-faktor yang Mempengaruhi...

Wimelda, Linda, dan Marlinah, A. 2013. Variabel-Variabel yang Mempengaruhi Struktur Modal pada Perusahaan Publik Sektor Non Keuangan. Media Bisnis, 5 (3): 200 - 213.

Wicaksana, I. G. A. 2012. Pengaruh Cash Ratio, Debt To Equity Ratio, dan Return On Asset terhadap Kebijakan Divien pada Perusahaan Manufaktur di Bursa Efek Indonesia. Tesis. Fakultas Ekonomi dan Bisnis Univesitas Udayana, Bali. 